\title{
Research on the Development of Badminton in Guizhou Normal College
}

\author{
Xiao-Fang Liu, Zu-Hua Xie, Ying Feng, Teng-Fei Yao, Jiang-Hua Li* \\ Key Lab of Training, Monitoring and Intervention of Aquatic Sports of General Administration of Sport of China, Institute of \\ Physical Education, Jiangxi Normal University \\ Nanchang, China
}

\begin{abstract}
At present, badminton has been becoming one of the most popular projects in China. At the same time, more and more students in colleges and universities are interested in badminton. It can be seen that the development of badminton plays a profound significance and a huge role in promoting the physical exercise in colleges and universities. Through the investigation and analysis of the status of badminton developed in Guizhou Normal College, this paper provides a reliable theoretical basis for the development of badminton in the normal colleges. By using the methods of logical analysis, mathematical statistics and questionnaire, a preliminary investigation on the status of badminton in Guizhou Normal College has been carried out. The results show that the most students in Guizhou Normal College are interested in badminton. The activities related to badminton are carried out in general good. However, the site facilities of badminton are relatively insufficient, the students' satisfaction is not high, and the utilization rate of indoor and outdoor venues is low. Besides these, one big problem for the students in Guizhou Normal College is that they have little chances to participate the badminton competitions at the provincial and municipal levels.
\end{abstract}

Keywords-Guiyang city; Colleges and universities; Badminton

\section{INTRODUCTION}

As an important gold medal in China's Olympic glory program, badminton has achieved excellent results in all previous international competitions [1]. This not only promotes the innovation and development of badminton technology in our country, but also greatly stimulates the enthusiasm of the public to participate in badminton. In recent years, some colleges and universities have held badminton competitions for teachers and students to make students and teachers feel a marked increase in physical and mental health [2]. It can be seen that the development of badminton play a profound significance and a huge role in promoting the development of colleges and universities.

The investigation and study of badminton in colleges and universities is guided by the "National Guide Curriculum Guide for Physical Education in Colleges and Universities". The Outline not only repositions the nature of PE curriculum, but also emphasizes that PE teaching must carry out the people-oriented education idea, Recognize the individual differences of students, attach importance to the overall development of student personality [3]. Badminton competitions with different competitions not only provide students with a platform to demonstrate their sports ability, but also reflect the implementation of the "Health First" thought in schools [4], which plays a guiding and promoting role in school sports.

Through the selection and study of badminton programs, students' interest and needs can be satisfied by different levels of students, more students can be engaged, their sports hobbies and expertise can be cultivated, the methods of scientific training can be mastered, their physical abilities can be improved, and a lifelong sport outlook can be established [5]. Through the research on the current situation of badminton in Guizhou Normal College, this paper provides a reliable theoretical basis for the development of badminton in this school, which will guide the teaching and practice of the teachers so as to make the students develop healthily.

\section{SUBJECTS AND METHODS}

\section{A. Subjects}

A total of 196 undergraduates were taken from Guiyang Teachers College, including 74 boys and 122 girls.

\section{B. Methods}

\section{1) Logical analysis}

In the process of compiling this article, this article discusses the theories and opinions of other scholars collected by using the logical methods of induction, deduction, analysis and synthesis, combined with the development of badminton in Guizhou Normal College.

2) Mathematical Statistics

Use Microsoft Excel to organize and analyze the data obtained.

\section{3) Questionnaire method}

According to the main purpose of this paper, in accordance with the basic principles of questionnaire design, according to the development of badminton in Guizhou Normal College, the author designed "the status quo and countermeasure of badminton in Guizhou Normal College Questionnaire." A total of 200 questionnaires were issued, 200 were recovered, the recovery rate of $100 \%, 196$ valid questionnaires, the effective 
recovery rate of $98 \%$. The test of validity of the questionnaire is judged by the expert judgment method. The reliability test adopts the repeated measurement method, and the correlation coefficient between the two questionnaires is greater than 0.70 . Therefore, the reliability of the questionnaire meets the statistical requirements.

\section{RESULTS AND DISCUSSION}

\section{A. Analysis of the Badminton Students' Cognitive Situation in Guizhou Normal College}

TABLE I. GUIZHOU NORMAL COLLEGE STUDENTS UNDERSTANDING OF BADMINTON

\begin{tabular}{|c|c|c|}
\hline \multirow{2}{*}{ Project } & Number & Percentage \\
\cline { 2 - 3 } & $(\boldsymbol{N})$ & $(\%)$ \\
\hline Know well & 4 & 2.1 \\
\hline Know & 60 & 30.6 \\
\hline Know a little & 108 & 55.1 \\
\hline Don't know & 24 & 12.2 \\
\hline
\end{tabular}

According to a survey of students' understanding of badminton in Guizhou Normal College, only $2.1 \%$ of the students knew very well the badminton knowledge; $30.6 \%$ said they understood the sport more than half; and more than half of the students said Know some, accounting for $55.1 \%$ of the total number of respondents; there are $12.2 \%$ of students do not know badminton. It can be seen, Guizhou Teachers College students understanding of badminton is considerable, with a good student base, in such circumstances is very suitable for badminton.

TABLE II. GUIZHOU NORMAL COLLEGE STUDENTS LOVE BADMINTON DEGREE

\begin{tabular}{|c|c|c|}
\hline \multirow{2}{*}{ Project } & Number & Percentage \\
\cline { 2 - 3 } & $(\boldsymbol{N})$ & $(\%)$ \\
\hline Very like & 28 & 14.3 \\
\hline Like & 90 & 45.9 \\
\hline General & 76 & 38.7 \\
\hline dislike & 2 & 1.1 \\
\hline
\end{tabular}

According to the results of the survey on the preference of badminton students in Guizhou Normal College, only $1.1 \%$ of students said they do not like badminton, $45.9 \%$ prefer the sport and $38.7 \%$ prefer badminton More general level, more $14.3 \%$ of students said they really like badminton. As can be seen from the above data, the badminton sport in Guizhou Normal College is loved and welcomed by the majority of students, with many badminton enthusiasts.

\section{B. Investigation and Analysis of Students Participation in Badminton in Guizhou Normal College}

TABLE III. A SURVEY OF STUDENTS PARTICIPATING IN BADMINTON IN GUIZHOU NORMAL COLLEGE EVERY WEEK

\begin{tabular}{|c|c|c|}
\hline \multirow{2}{*}{ Frequency } & Number & Percentage \\
\cline { 2 - 3 } & $(\boldsymbol{N})$ & $(\boldsymbol{\%})$ \\
\hline 0 Time & 48 & 24.5 \\
\hline 1Time & 92 & 46.9 \\
\hline 2 to 3 Times & 46 & 23.5 \\
\hline 4 Times or more & 10 & 5.1 \\
\hline
\end{tabular}

Through the analysis of survey data (as shown in table III), a survey on the participation of badminton students in Guizhou Normal College found that there were only 10 students who participated in badminton more than 4 times a week, accounting for $5.1 \%$ of the total number of inquiries. There are 46 people participating in 2 to 3 times a week, accounting for 23.5\%; students taking 1 and non-attendance each week account for $71.4 \%$ and 140 people respectively. The above data show that Guizhou Normal College students participate in badminton after class time enthusiasm is not high. Badminton after Guizhou Normal College need to further improve the badminton to improve the enthusiasm of students participation.

\section{Investigation and Analysis on the Development of Badminton Selective Course in Guizhou Normal College}

TABLE IV. THE NeCESSARY DEGREE OF STUDENTS SEIZING BADMINTON IN GUIZHOU NORMAL COLLEGE

\begin{tabular}{|c|c|c|}
\hline \multirow{2}{*}{ Project } & Number & Percentage \\
\cline { 2 - 3 } & $(\boldsymbol{N})$ & $(\%)$ \\
\hline Very necessary & 55 & 28.1 \\
\hline necessary & 129 & 65.8 \\
\hline General & 12 & 6.1 \\
\hline Not necessary & 0 & 0 \\
\hline
\end{tabular}

An analysis of the survey results shows that $93.9 \%$ of students think that it is necessary to set up a badminton course in Guizhou Normal College (see table IV), in which $28.1 \%$ of the total are deemed necessary and up to $65.8 \%$ of students think it is necessary Courses, only $6.1 \%$ of students think it is not necessary.

TABLE V. InVESTigation on the Evaluation of Elective Classes BY STUDENTS IN GUIZHOU NORMAL COLLEGE

\begin{tabular}{|c|c|c|c|}
\hline \multirow{2}{*}{ Project } & \multicolumn{3}{|c|}{ Can meet the needs of the course } \\
\cline { 2 - 4 } & can & General & Can not \\
\cline { 2 - 4 } & $(\%)$ & $(\%)$ & $(\%)$ \\
\hline Class content & 42.5 & 50 & 7.5 \\
\hline Technical mastery & 27.5 & 67.5 & 5 \\
\hline Class schedule & 32.5 & 52.5 & 15 \\
\hline Assessment method & 17.5 & 75 & 7.5 \\
\hline
\end{tabular}

As can be seen from table V, students in Guizhou Normal College are still satisfied with the lecture on badminton elective courses. Only $7.5 \%$ of students think they can't meet their current learning needs, while $42.5 \%$ of students think that the course The contents of the lectures can meet their needs. Only 
$27.5 \%$ of the students surveyed said that they could master some basic skills well, $67.5 \%$ of students said they had basic skills and $5.0 \%$ said they could not be in class Master these basic techniques. In the class schedule of badminton courses, $15 \%$ of students think that the current number of hours can't meet their needs, $32.5 \%$ of students think that they can meet their needs, $52.5 \%$ of students think it is normal; in badminton courses On the assessment method, $17.5 \%$ of the students considered the examination method as reasonable, but $7.5 \%$ of the students also considered the examination method unreasonable. There are still $75 \%$ of students think it is normal. As can be seen from these data, the badminton course in Guizhou Normal College still has a lot of deficiencies and needs to be further improved to meet the needs of students.

\section{Investigation on Satisfaction of Badminton Court Facilities in Guizhou Normal College}

TABLE VI. INVESTIGATION ON BADMINTON COURT SATISFACTION IN GUIZHOU NORMAL COLLEGE

\begin{tabular}{|c|c|c|}
\hline \multirow{2}{*}{ Project } & Number & Percentage \\
\cline { 2 - 3 } & $(\boldsymbol{N})$ & $(\%)$ \\
\hline Numerous & 4 & 2.0 \\
\hline Enough & 68 & 34.7 \\
\hline Insufficient & 106 & 54.1 \\
\hline Scarce & 18 & 9.2 \\
\hline
\end{tabular}

According to the survey (table VI), due to the lack of indoor space in Guizhou Normal College and the large number of classes, $63.3 \%$ of the students think the venue is not enough, affecting the class and training; $34.7 \%$ of the students think that the basic Adequate; only $2 \%$ of students think the venue is adequate. The data shows that the facilities and facilities of Guizhou Normal University are relatively scarce, and the students' satisfaction is not very high.

\section{E. Investigation and Analysis of Badminton Competition System in Guizhou Normal College}

TABLE VII. INVESTIGATION ON BADMINTON ASSOCIATION ORGANIZED ACTIVITIES IN GUIZHOU NORMAL COLLEGE

\begin{tabular}{|c|c|c|c|}
\hline \multirow{2}{*}{ Project } & \multicolumn{3}{|c|}{$\begin{array}{c}\text { Students understand Badminton Association } \\
\text { activities }\end{array}$} \\
\cline { 2 - 4 } & Often & Sometime & Don't know \\
\hline Number(N) & 78 & 100 & 18 \\
\hline Percentage (\%) & 39.8 & 51 & 9.2 \\
\hline
\end{tabular}

Table VII shows that $9.2 \%$ of the students think that the Badminton Association of Guizhou Normal University often organizes students' activities in badminton; $51 \%$ of students think badminton association occasionally organizes students in badminton activities; and the remaining $39.8 \%$ of students Do not know if the club organizes student activities in badminton. Badminton Association of Guizhou Normal University to carry out badminton activities overall situation is still good, but should also be strengthened badminton activities carried out, so that more students understand badminton, badminton.
TABLE VIII. INVESTIGATION ON BADMINTON EVENTS IN GUIZHOU NORMAL COLLEGE

\begin{tabular}{|c|c|c|c|}
\hline \multirow{2}{*}{ Project } & \multicolumn{3}{|c|}{$\begin{array}{r}\text { Students on all levels of badminton races to } \\
\text { understand the situation }\end{array}$} \\
\cline { 2 - 4 } & Participate & Don't participate & Don't know \\
\hline Provincial (\%) & 13.3 & 76.7 & 10 \\
\hline School level (\%) & 30 & 56.7 & 13.3 \\
\hline
\end{tabular}

As can be seen from table VIII, $13.3 \%$ of Guizhou Normal College students participated in provincial and municipal competitions, $30 \%$ of students participated in inter-school events; $76.7 \%$ of students did not participate in provincial-level events, $56.7 \%$ of students did not attend inter-school events. $10 \%$ of the students said they were not sure whether the school has organized provincial or municipal competitions, and $13.3 \%$ of the students said it was unclear whether the school organized or not participated in inter-school events. On the whole, Guizhou Normal College organized students to participate in badminton events are not optimistic, most students did not participate in badminton races.

\section{F. Analysis of the Restrictive Factors Existing in the Process of Badminton in Guizhou Normal College}

TABLE IX. INVESTIGATION ON BADMINTON EVENTS IN GUIZHOU NORMAL COLLEGE

\begin{tabular}{|c|c|c|}
\hline \multirow{2}{*}{ Constraints } & Number & percentage \\
\cline { 2 - 3 } & $(\boldsymbol{N})$ & $(\boldsymbol{\%})$ \\
\hline Lack of space & 127 & 64.8 \\
\hline Academic heavy & 39 & 19.9 \\
\hline Bad space & 18 & 9.2 \\
\hline other & 12 & 6.1 \\
\hline
\end{tabular}

Through the investigation and study found that $64.8 \%$ of students think that Guizhou Normal College badminton courts and equipment deficiencies, but can't meet the needs of students. Only $19.9 \%$ of students think they are overworked or have too little free time to participate in sports. Only $9.2 \%$ of the students think that the school's venues do not meet the standards, can't guarantee the badminton sport needs. $6.1 \%$ of students think it is caused by other factors (table IX).

\section{CONCLUSIONS AND RECOMMENDATIONS}

\section{A. Conclusions}

- Students of Guizhou Normal College have a good understanding of badminton and have a good student base.

- Badminton Association badminton activities in general the situation is good, but should also strengthen the race.

- At present, there are only 2 indoor badminton courts available in Guizhou Normal College (two are not yet in use), the indoor facilities are relatively scarce, and the students' satisfaction is not very high.

- The Badminton Elective Course at Guizhou Normal College did not do well. Most students did not attend the badminton course. Students were more interested in setting up the course. The number of students who 
participated in the elective course was significantly higher than that of the students who did not participate in the elective course. However, there were still many deficiencies in the timetable arrangement and assessment methods of the elective course, which needs further improvement to meet their needs.

- Guizhou Normal College students, to participate in provincial and municipal levels, inter-school competition less chance. On the whole, Guizhou Normal College organized students to participate in badminton events are not optimistic, most students did not participate in badminton races.

- The restrictive factors of badminton in Guizhou Normal College are mainly caused by the lack of space and students' over-schooling.

\section{B. Recommendations}

- Schools, colleges, badminton associations should provide as much as possible badminton courses, training, competitions, observing and other activities carried out.

- Ensure the necessary material conditions, increase the opening up and rectification of facilities and facilities on the site and increase the input of funds, overhaul and provision of aging venues and equipment. Badminton project should make full use of the school overhead layer to open at least two indoor plastic venues.
- Badminton teaching and scientific research should be strengthened so as to guide practice to continuously improve the quality of badminton training, deepen the teaching reform of badminton optional courses, improve the training system of badminton after class, and strive to serve the development of badminton in schools.

\section{ACKNOWLEDGMENT}

This work was supported by the Open Project Program of Key Lab of Training, Monitoring and Intervention of Aquatic Sports of General Administration of Sport of China, Jiangxi Normal University (NO. 201604).

\section{REFERENCES}

[1] G. Yang. Lifelong physical education under the sight of the public badminton teaching status quo and countermeasures [D].North east Normal University .2013. (In Chinese)

[2] W. Y. Zeng, J. J. Gu, X.C.Wang. Nanjing University badminton to carry out the status quo and countermeasures [J]. Nanjing Institute of Physical Education .2002, 16 (5): 109-110. (In Chinese)

[3] X.Zeng. Discussion on Improving Football Teaching in Technical Schools [J]. Contemporary Sports Science and Technology, 2012, 12 (7) (In Chinese)

[4] D.S.Zhang. Analysis of the influencing factors of outdoor badminton teaching in colleges and universities [J]. Shaanxi Education (Higher Education Edition). 2013 (12). (In Chinese)

[5] L.Weng. Current situation and countermeasures of badminton in colleges and universities [J]. Journal of Guangxi University for Nationalities, 2005, 11 (3): 99-101. (In Chinese) 